\title{
Influence of pasteurization on antioxidant and in vitro anti-proliferative effects of jambolan (Syzygium cumini (L.) Skeels) fruit pulp
}

\author{
Ivanise Guilherme Branco ${ }^{\mathrm{a}, *}$, Izabel Cristina Freitas Moraes ${ }^{\mathrm{b}}$, \\ Eliana Janet Sanjinez Argandoña ${ }^{c}$, Grasiele Scaramal Madrona ${ }^{d}$, Catarina dos Santos ${ }^{a}$, \\ Ana Lúcia Tasca Góis Ruiz ${ }^{\mathrm{e}}$, João Ernesto de Carvalho ${ }^{\mathrm{e}}$, \\ Charles Windson Isidoro Haminiuk ${ }^{\mathrm{f}}$ \\ a Departamento de Ciências Biológicas, Universidade Estadual Paulista (UNESP), 19806-900 Assis, SP, Brazil \\ b Departamento de Engenharia de Alimentos, Universidade de São Paulo (USP), 13636-000 Pirassununga, SP, Brazil \\ ' Faculdade de Engenharia, Universidade Federal da Grande Dourados (UFGD), 79804-070 Dourados, MS, Brazil \\ d Departamento de Engenharia de Alimentos, Universidade Estadual de Maringá (UEM), 87020-900 Maringá, PR, Brazil \\ e Centro Pluridisciplinar de Pesquisas Químicas, Biológicas e Agrícolas (CPQBA), Universidade Estadual de Campinas (UNICAMP),13081-970 Campinas, SP, \\ Brazil \\ ${ }^{\mathrm{f}}$ Departamento de Engenharia de Alimentos, Universidade Tecnológica Federal do Paraná (UTFPR), 873001-006 Campo Mourão, PR, Brazil
}

\section{A R T I C L E I N F O}

\section{Article history:}

Received 25 November 2015

Received in revised form 19 January 2016

Accepted 24 January 2016

Available online 21 May 2016

Keywords:

Syzygium cumini (L.) skeels

Jambolan

Pasteurization

Phenolic compounds

Antioxidant and anti-tumour effects

\begin{abstract}
A B S T R A C T
Here we analyze jambolan pulp phenolic compounds in order to establish a correlation with antioxidant and in vitro anti-proliferative effects, both before and after pasteurization. Total levels of phenolic compounds, flavonoids and anthocyanins were quantified using UV-vis techniques. Major phenolic compounds were identified by standard compound co-injection in HPLC-DAD/UV-vis. Antioxidant activity was measured by radical scavenging ability, as determined by DPPH assay. In vitro anti-proliferative activity was determined against nine human tumour cell lines using the methodology described by the Developmental Therapeutics Program at NCI/NIH. Pasteurization led to an increase in the levels of total soluble solids (6.7\%), phenolic compounds (7.2\%) and flavonoids (16.4\%). Anthocyanin content was largely preserved $(91 \%)$ when compared with pulp without treatment. S. cumini preserved $56 \%$ of its original antioxidant activity after pasteurization, while thermal treatment revealed cytostatic activity in kidney (786-0) and ovary (OVCAR-3) lineages. Therefore, pasteurization can be applied successfully to $S$. cumini pulp.
\end{abstract}

(C) 2016 Published by Elsevier B.V.

\section{Introduction}

Jambolan (Syzygium cumini (L.) Skeels), also known as jambolão, black plum, jamun or java plum, belongs to the Myrtaceae family. This plant possesses fruits that are oblong berries, deep purple or bluish in colour with a pinkish pulp. These fruits are widely consumed and also used for the treatment of various diseases as an astringent, antiscorbutic, diuretic, antidiabetic, anti-Leishmania (Rodrigues et al., 2015), and a treatment for chronic diarrhoea (Ayyanar and Subash-Babu, 2012). In addition to all of the abovedescribed properties, the fruit from the Jambolan (Syzygium cumini

\footnotetext{
* Corresponding author.

E-mail address: igbranco@assis.unesp.br (I.G. Branco).
}

(L.) Skeels) plant has also been reported to have strong antioxidant and anti-genotoxic potential (Baliga et al., 2011).

S. cumini fruit pulp is a source of phenolic compounds such as flavonoids and phenolic acids (Reynertson et al., 2008; Faria et al., 2011; Tavares et al., 2016). It also contains hydrolysable tannins, which may be the main phenolic compounds responsible for the astringency of the edible parts of fruit (Tavares et al., 2016), and anthocyanins: 3.5-diglucosides of delphinidin, petunidin and malvidin (Faria et al., 2011; Tavares et al., 2016), which are responsible for fruit pigment and are also thought to have antioxidant and anticancer bioactivity (Clifford, 2000; Nile and Park, 2014). Consuming these anthocyanin-rich fruits are described as a strategy to prevent cardiovascular diseases, cancer and neurodegenerative diseases (Oliveira et al., 2012). 
However, most studies published to date have essentially focused on raw foods, despite the fact that the human diet includes mainly cooked and processed foods. The domestic consumption of fruits may be either fresh or processed, including handmade frozen pulp, juice, jams, jellies and others. Industrial processing typically includes a heat treatment, such as drying, sterilisation and/or pasteurization, in order to destroy pathogenic microorganisms and inactivate enzymes, in order to increase shelf-life and availability of the product for consumption. However, such processing can drastically affect phenolic content and, as a consequence, the antioxidant capacity and anticancer bioactivities of foods formulated from these raw materials. For these reasons, anthocyanin-rich fruits, with few exceptions, have been poorly explored by the food industry, because they are with changes in temperature, $\mathrm{pH}$, oxygen and light (Turfan et al., 2011). Anthocyanins are the most sensitive, since they are also affected by the presence of metal ions, enzymes, ascorbic acid, and sulphur dioxide (Cavalcanti et al., 2011; Turfan et al., 2011).

The majority of studies found in the literature correlate the anti-proliferative activities and extracts of fruits in vitro with their polyphenolic compounds, but such studies have not examined the role of thermal treatment (Medina et al., 2011; Leite-Legatti et al., 2012; Neri-Numa et al., 2013; Zhang et al., 2013; RascónValenzuela et al., 2015). Therefore the functional properties of jambolan and the growing market demand for fruit pulps with flavor and colour, the pulp of this fruit shows high potential for use in the food processing industry, since this potential remains underexplored. Pasteurization is a heat treatment widely used in the fruit juice industry and the evaluation of changes/losses during this thermal processing is very important, because the use of high temperatures may result in a significant decrease in the concentration of bioactive compounds and consequently reduction of biological activity. In this context, considering the therapeutic potential of S. cumini pulp and the potential benefits for the human diet, we aimed to evaluate the influence of pasteurization during pulp-fruit processing on polyphenol levels in S. cumini pulp content. We then sought to correlate our findings with antioxidant and in vitro antiproliferative activity.

\section{Materials and methods}

\subsection{Chemical reagents}

The following reagents were purchased from Sigma Chemical Co.: 2,2-diphenyl-1-picrylhydrazil(DPPH), Folin-Ciocalteau and quercetin. Aluminium chloride hexahydrate, potassium acetate and gallic acid salts were obtained from Synth, as were solvents and acids.

\subsection{Processing and pasteurization of S. cumini pulp}

Jambolan fruits (Syzygium cumini (L.) Skeels) were collected at Paulista State University (UNESP), Campus of Assis-São Paulo State, during January and February 2011. Five kilograms of jambolan fruit were harvested from three plants (clones), then sanitised with chlorinated water $(25 \mathrm{ppm})$. The pits were removed, and the pulp was processed in a domestic processor. The pulp obtained was distributed in polyethylene bags and subsequently stored at $-18^{\circ} \mathrm{C}$ until the time of application. The jambolan pulp ( $100 \mathrm{~g}$ each) was submitted to pasteurization by heating in a water bath at $70^{\circ} \mathrm{C}$ for $5 \mathrm{~min}$ with stirring, followed by immediate cooling in an ice bath and storage at $-18^{\circ} \mathrm{C}$. The pulp, with or without thermal treatment, was submitted to analyzes of $\mathrm{pH}$, total acidity, moisture and soluble solids as described by AOAC (2000).

\subsection{Extract preparation}

Extracts were prepared according to Barreto et al. (2009), with some modifications. For every $10 \mathrm{~g}$ of jambolan pulp, $40 \mathrm{~mL}$ of methanol/water (8:2) was added. The solution was stirred for one hour. The mixture was then filtered in a Buchner funnel and washed using small portions of methanol. This step was performed two more times, using $20 \mathrm{~mL}$ of an 8:2 methanol/water solution. The filtrates were transferred to a volumetric flask, and the final volume was adjusted to $100 \mathrm{~mL}$. Extract levels of DPPH, flavonoids and phenolic compounds were analyzed. For HPLC and anti-proliferative activity analyzes, the extract obtained was then concentrated through a rota-evaporator at $40^{\circ} \mathrm{C}$ and lyophilised for $72 \mathrm{~h}$.

\subsection{Quantitative analysis of phenolic content}

Total phenolic content was estimated using the Folin-Ciocalteau colorimetric method, based on the procedure of Singleton and Rossi (1965). Quantitative measurements were performed based on a standard calibration curve generated with 100, 200, 300, 400 and $500 \mathrm{mg} / \mathrm{L}$ of gallic acid in $80 \%$ methanol. Total phenolic content was expressed as gallic acid equivalents (GAE) in grams per 100-g sample (mg GAE/100 g).

Total flavonoid content was determined using the methodology proposed by Chang et al. (2002). The extracts $(0.5 \mathrm{~mL})$ were mixed with $1.5 \mathrm{~mL}$ of $95 \%$ ethanol, $0.1 \mathrm{~mL}$ of $10 \%$ aluminium chloride hexahydrate, $0.1 \mathrm{~mL}$ of $1 \mathrm{M}$ potassium acetate and $2.8 \mathrm{~mL}$ deionised water. After 40-min incubation at room temperature, the absorbance of the reaction mixture was measured at $415 \mathrm{~nm}$. Results were expressed as milligrams of quercetin equivalents $(\mathrm{QE})$ per $100 \mathrm{~g}$ of sample ( $\mathrm{mg} \mathrm{QE} / 100 \mathrm{~g}$ ). The standard curve for quercetin was obtained with a concentration range of $0-50 \mathrm{mg} / \mathrm{L}$.

Radical scavenging activity was performed according to Rufino et al. (2010). First, a DPPH methanolic solution (0.06 mM) was prepared. Then, $100 \mu \mathrm{L}$ of fruit extract were added to $3.9 \mathrm{~mL}$ of DPPH solution. The decrease in absorbance at $515 \mathrm{~nm}$ was monitored once each minute until stabilisation. Antioxidant capacity was expressed as the sample concentration required to reduce the original amount of DPPH radicals by $50 \%\left(E_{50}\right)$, and values were expressed as $\mathrm{g}$ fruit/g DPPH.

Total anthocyanin content was determined according to Fuleki and Francis (1968a,b): extraction with ethanol and $\mathrm{HCl}(1.5 \mathrm{~N})$ $(85: 15)$ solution, followed by mixture filtration and analysis in a spectrophotometer at $535 \mathrm{~nm}$. Results were expressed as milligrams of cyanidin 3-glucoside (cyd 3-glu) equivalent per $100 \mathrm{~g}$ of fresh weight.

\subsection{Analysis by HPLC}

High-performance liquid chromatography coupled with ultraviolet-visible diode-array detection (HPLC-DAD/UV-vis) was performed in a Dionex UltiMate 3000 HPLC system (Dionex, Idstein, Germany) equipped with an UltiMate 3000 Pump, UltiMate 3000 Autosampler Column Compartment, UltiMate 3000 Photodiode Array Detector and Chromeleon software. A reversed phase Acclaim ${ }^{\circledR} 120$ column $(\mathrm{C} 18,5 \mu \mathrm{m}, 120 \AA$. $4.6 \mathrm{~mm} \times 250 \mathrm{~mm})$ was used for these experiments. The column temperature was held at $40^{\circ} \mathrm{C}$ for chromatographic separation. After $10 \mathrm{~min}$ of reequilibration, the column was ready for a new injection. Phenolic acids and flavonols are usually detected at wavelengths ranging from 210 to $320 \mathrm{~nm}$. The injection volume was $10 \mu \mathrm{L}(250 \mathrm{mg} / \mathrm{mL}$ in $40 \%$ ethanol). The mobile phase was a gradient of $1 \%$ phosphoric acid aqueous solution (A) and methanol (B). The gradient was as follows: 0-2 $\mathrm{min}, 0-15 \% \mathrm{~B}$; 2-5 min, $15-25 \% \mathrm{~B}$; 5-10 $\mathrm{min}, 25-30 \%$ B; $10-15$ min, 30-35\% B; 15-25 min, 35-50\% B; 25-30 min, 50-60\% 
B; 30-35 min, 60-80\% B; 35-45 min, 80-100\% B. The flow rate was set at $1 \mathrm{~mL} / \mathrm{min}$. The phenolic acids (gallic acid, chlorogenic acid, caffeic acid, $p$-coumaric acid, ferulic acid) and flavonols (rutin, myricetin, quercetin and kaempferol) standards (Sigma Chemical Co.) were applied. Stock solutions of all standards were prepared in methanol. For the HPLC analysis, phenolic compounds were identified by comparing their retention times with those of pure standards (Granato et al., 2011).

\subsection{In vitro anti-proliferative activity}

Anti-proliferative activity was screened using the methodology described by the Developmental Therapeutics Program at NCI/NIH (Monks et al., 1991; available at http://dtp.nci.nih.gov/ ). A non-tumour cell line, VERO (epithelial cells of monkey kidney), and the following human tumour cell lines were obtained from the National Cancer Institute (Frederick, MA, USA): U251 (glioma), UACC-62 (melanoma), MCF-7 (breast), NCI-ADR/RES (ovarian-expressing phenotype multiple-drug resistance), 786-0 (renal), NCI-H460 (lung, non-small cell), PC-3 (prostate), OVCAR03 (ovarian), and K562 (leukaemia). Stock cultures were grown in medium containing $5 \mathrm{~mL}$ RPMI 1640 (GIBCO BRL) supplemented with $5 \%$ foetal bovine serum (FBS, GIBCO) at $37{ }^{\circ} \mathrm{C}$ with $5 \% \mathrm{CO}_{2}$. A penicillin:streptomycin mixture $(1000 \mu \mathrm{g} / \mathrm{L}: 1000 \mathrm{U} / \mathrm{L}, 1 \mathrm{~mL} / \mathrm{L})$ was added to the experimental cultures. Cells in 96-well plates $(100 \mu \mathrm{L}$ cells $\times$ well $^{-1}$ ) were exposed to extracts in DMSO (Merck)/RPMI $\left(0.25,2.5,25\right.$, and $\left.250 \mu \mathrm{g} \times \mathrm{mL}^{-1}\right)$ at $37{ }^{\circ} \mathrm{C}, 5 \% \mathrm{CO}_{2}$ in air for $48 \mathrm{~h}$. The final DMSO concentration (less than $0.2 \%$ ) did not affect cell viability. Before ( $T_{0}$ plate) and after sample addition ( $T_{1}$ plates), cells were fixed with $50 \%$ trichloroacetic acid. The level of cell proliferation was determined by spectrophotometric quantification $(540 \mathrm{~nm})$ of cellular protein content using the sulphorhodamine B assay. Using the concentration-response curve for each cell line, the $\mathrm{GI}_{50}$ (concentration that produces $50 \%$ growth inhibition) was determined through non-linear regression analysis using ORIGIN $8.5{ }^{\circledR}$ software (OriginLab Corporation) (Vendramini-Costa et al., 2010).

\subsection{Statistical analysis}

The results were expressed as mean values \pm standard deviation from two extraction replicates, each run in triplicate. The analysis of variance (ANOVA) was determined using SAS software (version 9.2, SAS Institute, Cary, N.C., USA). The means were compared using Tukey's test. Statistical significance was set at a level of $\mathrm{p}<0.05$. Correlation and regression analyzes were performed using ORIGIN $8.5^{\circledR}$ software (OriginLab Corporation).

\section{Results and discussion}

Our results regarding the $\mathrm{pH}$ and total soluble solid levels of the Syzygium cumini pulp are compatible with those reported in the literature (Mussi et al., 2015; Tavares et al., 2016). Previous reports described S. cumini as an acidic fruit with $\mathrm{pH}$ ranging from 3.29 to 4.04 and soluble solid content ranging from 11.4 to 11.76 Brix. Acidity is an advantage in $S$. cumini pulp, because intensive heat treatment is not necessary, as bacteriological development does not take place at these $\mathrm{pH}$ levels. In this study, we found higher levels of soluble content (about 18 Brix) than those described by Mussi et al. (2015). Highly soluble content is important, because less sugar will need to be added and less time will be required for the water to evaporate. These factors require the expenditure of less energy, resulting in a more economical process with increased product yield (Pereira et al., 2012). Therefore, S. cumini is a good candidate for industrial processing (Table 1 ).

Differences in phenol, anthocyanin and flavonoid levels are usually related to variations in the methodologies employed in
Table 1

Physical-chemical, phenolic compounds and anti-radical activity determined in jambolan pulp with or without pasteurization (fresh matter).

\begin{tabular}{lcc}
\hline & $\begin{array}{l}\text { Without } \\
\text { Pasteurization }\end{array}$ & $\begin{array}{l}\text { With } \\
\text { Pasteurization }\end{array}$ \\
\hline $\mathrm{pH}$ & $4.15^{\mathrm{a}} \pm 0.20$ & $4.12^{\mathrm{a}} \pm 0.30$ \\
Moisture (\%) & $86.07^{\mathrm{a}} \pm 0.003$ & $84.76^{\mathrm{b}} \pm 0.001$ \\
Soluble Solids ( ${ }^{\circ}$ Brix) & $17.80^{\mathrm{a}} \pm 0.20$ & $19.00^{\mathrm{b}} \pm 0.17$ \\
Total phenolics (mg GAE/100 g) & $206.95^{\mathrm{a}} \pm 1.11$ & $221.83^{\mathrm{b}} \pm 0.60$ \\
Total anthocyanin (mg cyd & $213.00^{\mathrm{a}} \pm 1.02$ & $195.00^{\mathrm{b}} \pm 0.72$ \\
3-Glu/100g sample) & & \\
Total flavonoids (mg QE/100 g) & $25.29^{\mathrm{a}} \pm 0.22$ & $29.45^{\mathrm{b}} \pm 2.15$ \\
$\begin{array}{l}\text { Antioxidant capacity EC } \\
\text { (gfruit/gDPPH) }\end{array}$ & $53.25^{\mathrm{a}} \pm 2.93$ & $83.16^{\mathrm{b}} \pm 9.78$ \\
& & \\
\hline
\end{tabular}

Results expressed as mean \pm standard deviation; Different letters indicate significant difference between means in the same line (Tukey's test $\mathrm{p} \leq 0.05$ ); GAE: gallic acid equivalent; cyd 3-glu: cyanidin 3-glucoside; QE:quercetin equivalent; EC50: Concentration of antioxidant required to reduce the original amount of free radicals by $50 \%$.

sample extraction, reaction conditions, and other factors that affect fruit composition. Total phenolic content was higher in this study as compared to the results reported by Rufino et al. (2010) (185 mg/100 g fresh matter) and Faria et al. (2011) (148.3 mg/100 g of fresh matter). Similarly, total flavonoid content (Table 1) was much higher in this study as compared to the results reported by Benherlal and Arumughan (2007) ( $7 \mathrm{mg} / 100 \mathrm{~g}$ fresh matter) but lower when compared to the results reported by Faria et al. (2011) (91.2 mg of cathechin equivalent/100 g sample). Sultana and Anwar (2008) found total flavonol (kaempeferol, quercetin, myricetin) values of $0.24 \mathrm{mg} / 100 \mathrm{~g}$ dry matter and quercetin levels of $0.12 \mathrm{mg} / 100 \mathrm{~g}$ dry matter in jambolan pulp. The anthocyanin content in our experiments was higher than the results obtained by Benherlal and Arumughan (2007) (134 mg cyanidin3-glucoside/100 g fresh weight) and by Rufino et al. (2010) ( $93.3 \mathrm{mg} / 100 \mathrm{~g}$ fresh matter) but lower than that obtained by Mussi et al. (2015) and similar to levels reported by Faria et al. (2011) (211 mg/100g).

The next step will be to analyze differences in the phenolic composition profile induced by the pasteurization of $S$. cumini pulp. These values should then be compared to those obtained without thermal treatment. In this study, pasteurization did not affect Syzygium cumini pulp pH and increased total soluble solid content (about 6.7\%), as shown in Table 1.

Total phenolic and flavonoid levels showed an increase after pasteurization (about $7.2 \%$ and $16.4 \%$, respectively) with a reduction in anthocyanin content (about 8.5\%). Decreases in total phenolic and flavonoid levels (especially anthocyanins) induced by changes in temperature are well described in the literature. Brownmiller et al. (2008) reported a 43\% decrease in total anthocyanin content in blueberry purees after pasteurization. Turfan et al. (2011) evaluated the stability of anthocyanins after pasteurization $\left(95^{\circ} \mathrm{C} / 10 \mathrm{~min}\right)$ during the processing of pomegranate anthocyanins (Punica granatum L., cv. Hicaznar) and verified a loss of $8-14 \%$. Patras et al. (2009) reported that anthocyanin and phenol levels in strawberry and blackberry purees were also affected by thermal processing $\left(70^{\circ} \mathrm{C} / 2 \mathrm{~min}\right)$, which showed that pasteurization reduced flavonoid levels in fruit purées. Zoric et al. (2014) noted that the duration of heating as well as the temperature used impacted anthocyanin degradation more than that of other phenols.

Mussi et al. (2015) described a reduction in anthocyanin content (60-70\%) when processing S. cumini residue, but antioxidant activity levels still ranged from 93 to $97 \%$. The authors did not correlate this trend with activity levels for other phenolic compounds. In this study, total anthocyanin and antioxidant activity levels were reduced after pasteurization (about $8.5 \%$ and 56\%, respectively) 
Table 2

Quantification and chromatographic and spectroscopic characteristics of non-anthocyanic phenolic compounds from jambolan pulp obtained by HPLC-DAD.

\begin{tabular}{|c|c|c|c|c|}
\hline Compounds & $\mathrm{t}_{\mathrm{R}}(\min )$ & $\lambda(\mathrm{nm})$ & $\begin{array}{l}\text { Without pasteurization } \\
\text { (mg/Kg of fresh weight) }\end{array}$ & $\begin{array}{l}\text { With pasteurization } \\
\text { ( } \mathrm{mg} / \mathrm{Kg} \text { of fresh weight }\end{array}$ \\
\hline Gallic acid ${ }^{*}$ & 6.71 & 272 & $28.04^{\mathrm{a}} \pm 0.93$ & $44.04^{b} \pm 1.90$ \\
\hline Chlorogenic acid & 10.12 & 280 & $205.60^{\mathrm{b}} \pm 6.01$ & $93.08^{a} \pm 2.51$ \\
\hline Ferulic acid ${ }^{*}$ & 18.45 & 280 & $7.81 \pm 0.23$ & n.d. \\
\hline Rutin $^{*}$ & 19.88 & 370 & $5.96 \pm 0.34$ & n.d. \\
\hline Myricetin & 27.33 & 215,338 & $35.40^{\mathrm{b}} \pm 0.85$ & $23.56^{a} \pm 0.79$ \\
\hline Quercetin & 31.60 & 370 & $4.52^{\mathrm{a}} \pm 0.22$ & $5.16^{\mathrm{b}} \pm 0.28$ \\
\hline Total & & & $287.33^{b} \pm 5.98$ & $165.84^{\mathrm{b}} \pm 4.78$ \\
\hline
\end{tabular}

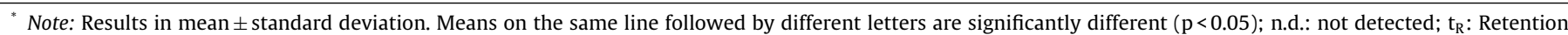
time, $\lambda$ : Wavelength.

Table 3

Antiproliferative activity $\left(\mathrm{GI}_{50}, \mu \mathrm{g} / \mathrm{mL}\right)$ of doxorubicin and jambolan extracts against human cell lines.

\begin{tabular}{|c|c|c|c|c|c|c|c|c|c|}
\hline & 2 & $\mathrm{u}$ & $\mathrm{m}$ & $\mathrm{a}$ & 7 & 4 & o & $\mathrm{h}$ & $\mathrm{q}$ \\
\hline doxorubicin (positive control) & $0.05 \pm 0.04$ & $<0.025$ & $<0.025$ & $0.18 \pm 0.01$ & 0.025 & $<0.025$ & $<0.025$ & $0.22 \pm 0.01$ & $<0.025$ \\
\hline without pasteurization & $>250$ & $<0.25$ & $>250$ & $1.21 \pm 0.17$ & $>250$ & $>250$ & $>250$ & $>250$ & $>250$ \\
\hline with pasteurization & $>250$ & $>250$ & $>250$ & $193.5 \pm 7.71$ & $3.8 \pm 2.2$ & $>250$ & $53.7 \pm 39.0$ & $>250$ & $>250$ \\
\hline
\end{tabular}

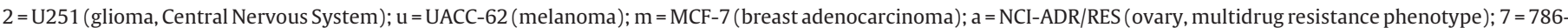
0 (kidney); 4 = NCI-H460 (lung, non-small cells adenocarcinoma); o= OVCAR-3 (ovary); h= HT-29 (colon); q= HaCaT (keratinocyte human, immortalized normal cell).

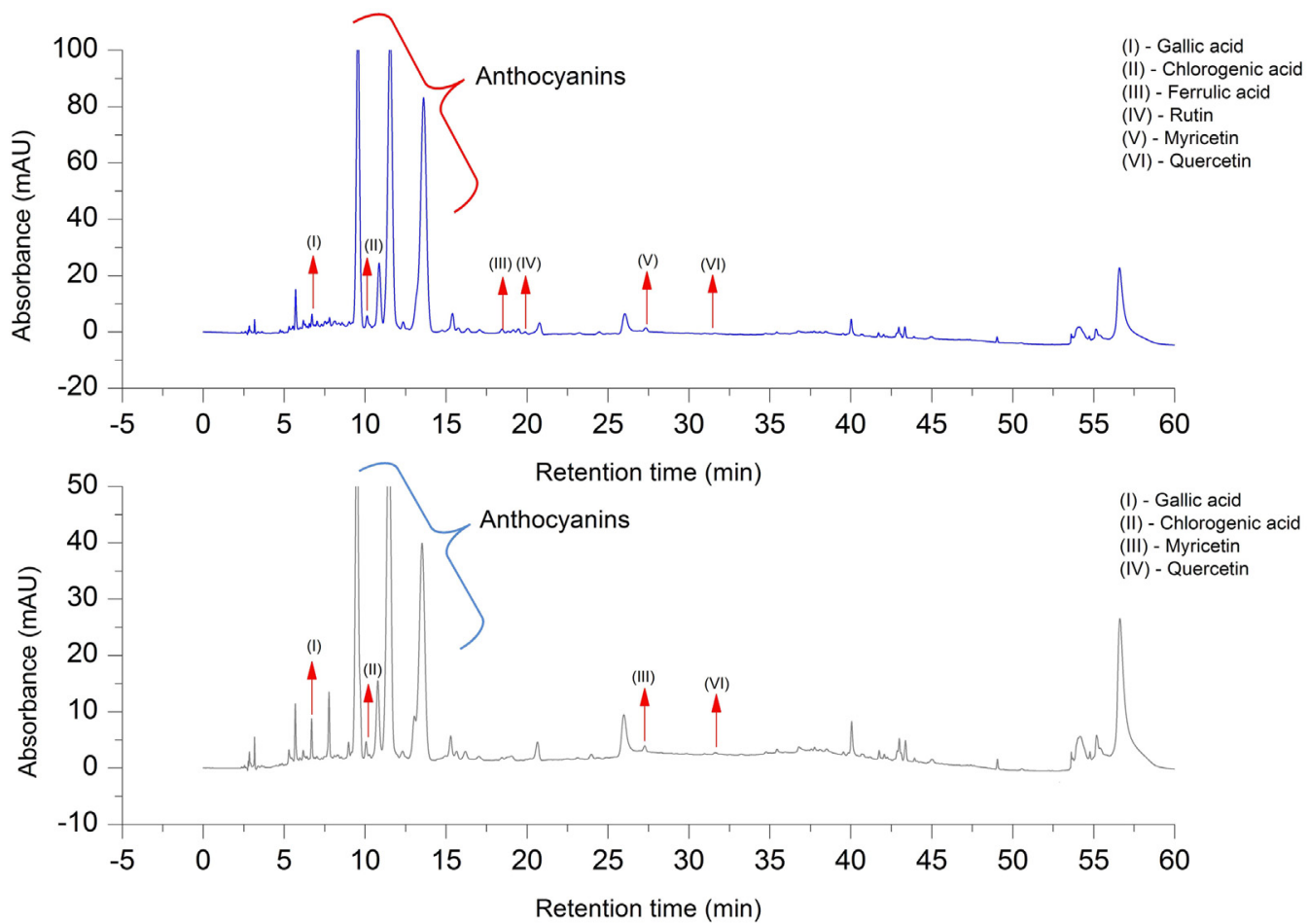

Fig. 1. Chromatographic profile of jambolão pulp without (top) and with (bottom) pasteurization at $280 \mathrm{~nm}$.

(Table 1). Therefore, we suggest that flavonoids and phenolic acids are as important as anthocyanins for the free radical scavenging of $S$. cumini pulp. Some studies about the antioxidant potential of phenolic compounds in fruits or foods have demonstrated the existence of synergistic or antagonistic effects among the various antioxidants present in the food matrix; thus, activity not only depends on flavonoids and/or phenolic structure but also on the environment in which said compounds are found (Palafox-Carlos et al., 2012; Ioannou et al., 2012).

Even so, S. cumini pulp pasteurization remains advantageous, because the process induces only limited anthocyanin loss, which allows the pulp to be used as a functional ingredient in several processed products that require the incorporation of fruit pulp, such as preserves, juices, nectar, ice cream, and yogurt. However, the medium must be slightly acidic to preserve the characteristic colour of the fruit.

For the HPLC-DAD analysis, phenolic assessments were carried out by UV-vis analyzes, by comparing the retention times $\left(t_{R}\right)$ for available standards and by considering information from the literature. Three major peaks on the chromatogram shown in Fig. 1 were identified as the anthocyanins. The first peak, with a retention time of $9.4 \mathrm{~min}$ (UV absorption at 275 and $522.2 \mathrm{~nm}$ ), may represent delphinidin 3-diglucoside. The second peak, with a retention time of $10.3 \mathrm{~min}$ (UV absorption at 274 and $524 \mathrm{~nm}$ ), likely indicates the presence of delphinidin 3,5-diglucoside. The third peak at $13.4 \mathrm{~min}$ (UV absorption at 275 and $525 \mathrm{~nm}$ ) suggests the existence of petunidin-3,5 diglucoside. These results are similar to those described by Faria et al. (2011), who found five types of anthocyanin 
aglycones in S. cumini pulp: delphinidin, cyanidin, petunidin, malvidin and peonidin. Comparisons of jambolan pulp measurements with the retention times of authentic standards allowed us to identify phenolic acids (gallic acid: $6.71 \mathrm{~min}$, chlorogenic acid: $10.1 \mathrm{~min}$, ferrulic acid: $18.4 \mathrm{~min}$ ) and flavonoid (rutin: $19.9 \mathrm{~min}$ ). Myricetin (27.3 $\mathrm{min}$ ) and quercetin derivatives ( $31.6 \mathrm{~min}$ ) were also detected and confirmed by UV absorption ( 215 and $338 \mathrm{~nm}, 370 \mathrm{~nm}$, respectively). These results (Table 2) are similar to those described by Faria et al. (2011).

In Table 2, the results of HPLC quantification show that pasteurization increased gallic acid levels by $57 \%$ and quercetin levels by $14 \%$, but there was a significant decrease in chlorogenic acid and myricetin levels (about 54\% and 33\%, respectively). Neither ferulic acid nor rutin was detected after pasteurization. The increase in gallic acid after pasteurization may be directly related to the cleavage of covalent bonds and the release of this molecule to the medium. However, the mechanism underlying the decrease in rutin content that accompanied the increase in quercetin remains elusive. At first, the increase in quercetin might seem to be related to the decrease in rutin glucose, but quercetin is less resistant to increased temperature than is rutin (Ioannou et al., 2012).

Ioannou et al. (2012) also described, in their revision, the fact that it is not easy to dissociate the effect of thermal processing from food matrix effects, because the degradation of flavonoids is not only a function of temperature and the duration of heating; it may also depend on other parameters such as $\mathrm{pH}$, the presence of oxygen and the presence of other phytochemicals in the medium. Regarding $\mathrm{pH}$, the degradation of rutin and quercetin is enhanced under weakly alkaline and neutral reaction conditions. Notably, S. cumini pulp is acidic. Alternately, the process could be oxidative, because the presence of high concentrations of oxygen induces quercetin and rutin degradation, while the absence of oxygen has the opposite effect. However, Ioannou et al. stated that other phytochemicals such as chlorogenic acid in the medium may play a protective role, which could explain the medium presence of quercetin and maybe myricetin, because the latter compound is found in S. cumini pulp.

In this work, the anti-proliferative activity of the tested compounds was expressed as the concentration that produced $50 \%$ cell growth inhibition or a cytostatic effect $\left(\mathrm{GI}_{50}, \mathrm{mg} / \mathrm{mL}^{-1}\right)$ for each cell line (Table 3).

For S. cumini pulp, optimal results with regard to selectivity and cytostatic effects on growth inhibition among the cells tested before pasteurization were found for the melanoma cell line (UACC-62, $\mathrm{GI}_{50}<0.25 \mathrm{mg} / \mathrm{mL}$ ), followed by the resistant ovarian cell line $\left(\mathrm{NCI}-\mathrm{ADR} / \mathrm{RES}, \mathrm{GI}_{50}=1.21 \mu \mathrm{g} / \mathrm{mL}\right)$, where significant cytostatic activity was observed. After pasteurization, $S$. cumini presented a weak inhibitory effect on the growing ovary cell line (OVCAR-3, $\left.\mathrm{GI}_{50}=53.7 \mu \mathrm{g} / \mathrm{mL}\right)$ and significant selectivity and cytostatic effects on the inhibition of growing kidney cell lines $\left(786-0, \mathrm{GI}_{50}=3.7 \mu \mathrm{g} / \mathrm{mL}\right.$ ) (Table 3 ). These differences in the anti-proliferative profile may be explained by chemical changes promoted by heat treatment as indicated by total phenolic, anthocyanin and flavonoid levels (Table 1) and HPLC analysis (Table 2, Fig. 1). Although the pulp had high selectivity for those cell lines, it showed weak anti-proliferative activity against other cancer cell lines and HaCat cells; i.e., pulp did not affect the proliferation of normal cells, making it an excellent candidate nutraceutical food.

\section{Conclusion}

These findings suggest that pasteurization can be applied successfully to $S$. cumini pulp. The $\mathrm{pH}$ as well as total soluble solid, total phenol and flavonoid levels were increased. Despite the overall reduction in anthocyanin content and antioxidant activity in pasteurised as compared to non-pasteurised pulp, pasteurised pulp demonstrated robust in vitro anti-proliferative activity in kidney cells (786-0) and weak in vitro anti-proliferative activity in ovarian cells (OVCAR-3), without affecting the proliferation of normal cells (HaCat cells).

Therefore, S. cumini pulp pasteurization is advantageous: with limited anthocyanin loss, fruit colour was preserved. S. cumini pulp could therefore be used as an additive in medicines and foods, provided that they are slightly acidic. Moreover, the pulp preserves a portion of the initial antioxidant capacity and anti-proliferative activity present prior to the pasteurization process, making it a good candidate for a nutraceutical food. Further studies evaluating other pulp-processing conditions will be required to increase the product's shelf-life, thus preserving its health benefits and contributing to the intake of anthocyanins and other polyphenolic compounds.

\section{References}

AOAC, 2000. Official Methods of Analysis, 17th ed. AOAC International, Gaithersburg, Md.

Ayyanar, M., Subash-Babu, P., 2012. Syzygium cumini (L.) Skeels: a review of its phytochemical constituents and traditional uses. Asian Pac. J. Trop. Biomed. 2, 240-246.

Baliga, M.S., Bhat, H.P., Baliga, B.R.V., Palatty, P.L., 2011. Phytochemistry, traditional uses and pharmacology of Eugenia jambolana Lam. (black plum): a review. Food Res. Int. 44, 1776-1789.

Barreto, G.P.M., Benassi, M.T., Mercadante, A.Z., 2009. Bioactive compounds from several tropical fruits and correlation by multivariate analysis to free radical scavenger activity. J. Braz. Chem. Soc. 20, 1856-1861.

Benherlal, P.S., Arumughan, C., 2007. Chemical composition and in vitro antioxidant studies on Syzygium cumini fruit. J. Sci. Food Agric. 87, 2560-2569.

Brownmiller, C., Howard, L.R., Prior, R.L., 2008. Processing and storage effects on monomeric anthocyanins percent polymeric color, and antioxidant capacity of processed blueberry products. J. Food Sci. 73, H72-H79.

Cavalcanti, R.N., Santos, D.T., Meireles, M.A.M.A., 2011. Non-thermal stabilization mechanisms of anthocyanins in model and food systems-an overview. Food Res. Int 44, 499-509.

Chang, C.C., Yang, M.H., Wen, H.M., Chern, J.C., 2002. Estimation of total flavonoid content in propolis by two complementary colorimetric methods. J. Food Drug Anal. 10, 178-182

Clifford, M.N., 2000. Anthocyanins-nature, occurrence and dietary burden. J. Sci. Food Agric. 80, 1063-1072.

Faria, A.F., Marques, M.C., Mercadante, A., 2011. Identification of bioactive compounds from jambolão (Syzygium cumini) and antioxidante capacity evaluation in diferente $\mathrm{pH}$ conditions. Food Chem. 126, 1571-1578.

Fuleki, T., Francis, F.J., 1968a. Quantitative methods for anthocyanins. 1. Extraction and determination of total anthocyanin in cranberries. J. Food Sci. 33, 72-77.

Fuleki, T., Francis, F.J., 1968b. Quantitative methods for anthocyanins. 2. Determination of total anthocyanin and degradation index for cranberry juice. J. Food Sci. 33, 78-83.

Granato, D., Katayama, F.C.U., de Castro, I.A., 2011. Phenolic composition of South American red wines classified according to their antioxidant activity, retail price and sensory quality. Food Chem. 129, 366-373.

Ioannou, I., Hafsa, I., Hamdi, S., Charbonnel, C., Ghoul, M., 2012. Review of the effects of food processing and formulation on flavonol and anthocyanin behavior. J. Food Eng. 111, 208-217.

Leite-Legatti, A.V., Batista, A.G., Dragano, N.R.V., Marques, A.C., Malta, L.G., Riccio, M.F., Eberlin, M.N., Machado, A.R.T., Carvalho-Silva, L.B., Ruiz, A.L.T.G., Carvalho, J.E., Pastore, G.M., Maróstica Júnior, M.R., 2012. Jaboticaba peel Antioxidant compounds, antiproliferative and antimutagenic activities. Food Res. Int. 49, 596-603.

Medina, A.L., Haas, L.I.R., Chaves, F.C., Salvador, M., Zambiazi, R.C., Silva, W.P., Nora, L., Rombaldi, C.V., 2011. Araçá (Psidium cattleianum Sabine) fruit extracts with antioxidant and antimicrobial activities and antiproliferative effect on human cancer cells. Food Chem. 128, 916-922.

Monks, A., Scudiero, D., Skehan, P., Shoemaker, R., Paull, K., Vistica, D., Hose, C., Langley, J., Cronise, P., Vaigro-Wolff, A., Gray-Groodich, M., Campbell, H., Mayo, J., Boyd, M., 1991. Feasibility of a high-flux anticancer drug screen using a diverse panel of cultured human cell lines. J. Natl. Cancer Inst. 83, 757-766.

Mussi, L.P., Guimarães, A.O., Ferreira, K.S., Pereira, N.R., 2015. Spouted bed drying of jambolão (Syzygium cumini) residue Drying kinetics and effect on the antioxidant activity, anthocyanins and nutrients contents. Food Sci. Technol. $61,80-86$.

Neri-Numa, I.A., Carvalho-Silva, L.B., Morales, J.P., Malta, L.G., Muramoto, M.T., Ferreira, J.E.M., Carvalho, J.E., Ruiz, A.L.T.G., Maróstica Júnior, M.R., Pastore, G.M., 2013. Evaluation on the oxidant: antiproliferative and antimutagênic potential of araçá-boi fruit (Eugenia stipitata Mc Vaugh-Myrtaceae) of the Brazilian Amazon Forest. Food Res. Int. 50, 70-76.

Nile, S.H., Park, S.W., 2014. Edible berries: bioactive componentes and their effect on human health. Nutrition 30,134-144. 
Oliveira, V.B., Yamada, L.T., Fagg, C.W., Brandão, M.G.L., 2012. Native foods from Brazilian biodiversity as a source of bioactive biocomponds. Food Res. Int. 48, 170-179.

Palafox-Carlos, H., Gil-Chávez, J., Sotelo-Mundo, R.R., Namiesnik, J., Gorinstein, S. González-Aguilar, G.A., 2012. Antioxidant interactions between major phenolic compounds found in 'Ataulfo' mango pulp: chlorogenic, gallic protocatechuic and vanillic acids. Molecules 17, 12657-12664.

Patras, A., Bruton, N.P., Da Pieve, S., Butler, F., 2009. Impact of high pressure processing on total antioxidant activity phenolic, ascorbic acid, anthocyanin content and colour of strawberry and blackberry purées. Innovative Food Sci. Emerging Technol. 10, 308-313.

Pereira, M.C., Steffens, R.S., Jablonski, A., Hertz, P.F., Rios, A.O., Vizzotto, M., Flôres, S.H., 2012. Characterization and antioxidant potential of Brazilian fruits from the myrtaceae family. J. Agric. Food Chem. 60, 3061-3067.

Rascón-Valenzuela, L., Jiménez-Estrada, M., Velázquez-Contreras, C., Garibay-Escobar, A., Vilegas, W., Campaner, L., Coqueiro, A., Robles-Zepeda, R.E., 2015. Chemical composition and antiproliferative activity of Acalypha californica. Ind. Crops Prod. 69, 48-54.

Reynertson, K.A., Yang, H., Jiang, B., Basile, M.J., Kennelly, E.J., 2008. Quantitative analysis of antiradical phenolic constituents from fourteen edible Myrtaceae fruits. Food Chem. 109, 883-890.

Rodrigues, K.A.F., Amorim, L.V., Dias, C.N., Moraes, D.F.C., Carneiro, S.M.P., Carvalho, F.A.A., 2015. Syzygium cumini (L.) Skeels essential oil and its major constituent $\alpha$ - pinene exhibit anti-leishmania activity through immunomodulation in vitro. J. Ethnopharmacol. 160, 32-40.

Rufino, M.S.M., Alves, R.E., Brito, E.S., Pérez-Jiménez, J., Saura-Calixto, F., Mancini-Filho, J., 2010. Bioactive compounds and antioxidant capacities of 18 non-traditional tropical fruits from Brazil. Food Chem. 12, 996-1002.
Singleton, V.L., Rossi Jr., J.A., 1965. Colorimetry of total phenolics with phosphomolybdic-phosphotungstic acid reagents. Am. J. Enol. Vitic. 16, 144-158.

Sultana, B., Anwar, F., 2008. Flavonols (kaempeferol quercetin, myricetin) contentes of selected fruits, vegetables and medicinal plants. Food Chem. 108, $879-884$.

Tavares, I.M.C., Lago-Vanzela, E.S., Rebello, L.P.G., Ramos, A.F., Gómez-Alonso, S., García-Romero, E., Da-Silva, R., Hermosín-Gutiérrez, I., 2016. Comprehensive study of the phenolic composition of the edible parts of jambolan fruit (Syzygium cumini (L.) Skeels). Food Res. Int. 82, 1-13.

Turfan, Ö., Türkyilmaz, M., Yemis, O., Özkan, M., 2011. Anthocyanin and colour changes during processing of pomegranate (Punica granatum L., cv. Hicaznar) juice from sacs and whole fruit. Food Chem. 129, 1644-1651.

Vendramini-Costa, D.B., Castro, I.B.D., Ruiz, A.L.T.G., Marquissolo, C., Pilli, R.A., Carvalho, J.E., 2010. Effect of goniothalamin on the development of Ehrlich solid tumor in mice. Bioorg. Med. Chem. 18, 6742-6747.

Zhang, L., Chen, H., Tian, J., Chen, S., 2013. Antioxidant and anti-proliferative activities of five compounds from Schisandra chinensis fruit. Ind. Crops Prod. 50, 690-693.

Zoric, Z., Dragovic-Uzelac, V., Pedisic, S., Kurtanjek, Z., Garofulic, I.E., 2014. Kinetics of the degradation of anthocyanins: phenolic acids and flavonols during heat treatments of freeze-dried sour cherry marasca paste. Food Technol. Biotechnol. 52, 101-108. 